\title{
Chapter 10 \\ History Education in Japan: An Account of Domestic Policy Controversies Over the Past War
}

\author{
Masako Shibata
}

\subsection{Introduction}

This chapter deals with a number of important themes of history education, including perceptions of the nation, the notions of collective memory, state policy for education and the interrelationships of these themes. Within this thematic framework, it looks at controversies over the policies of the Ministry of Education for history education in Japan regarding the Battle of Okinawa (March-June 1945) ${ }^{1}$ in World War II (WWII), in which the war-time Japanese are remembered as both aggressors and victims. It also explores the geneses of the controversies, trailing the political and social positioning of Okinawa in the process of Japan becoming a modern state from the late nineteenth century.

In Japan and around the world, the war has been interpreted in a variety of perspectives. More often than not, they raised cases in academic and political discussions, which have brought about many 'histories' of the war. At the same time, reconciliation among countries and peoples involved in the war became a popular scene. Particularly from the turn of the century, a number of governments and the state leadership began to review the conventional aloof posture on war-time wrongdoings by their country, and try to amend the past injustices by offering official apologies to victims.

Notwithstanding this unparalleled trend of the so-called 'age of apology' in the history of modern state, the government and the Ministry of Education in Japan

\footnotetext{
${ }^{1}$ While some textbooks note that the Battle started on 1 April when the US troops landed in the Okinawa Island (main island), while others adopt the starting date of 26 March when the first US troops landed in part of Okinawa Prefecture, the Kerama Islands, where 55\% of the 'group suicides' took place (Ryukyu Shimpo 2014, p. 38).
}

\section{Shibata $(\bowtie)$}

Doctoral Program in International and Advanced Japanese Studies, School of Humanities and Social Sciences, University of Tsukuba, Tsukuba, Japan

e-mail: shibata.masako.ga@u.tsukuba.ac.jp 
have been having difficulties in accommodating longstanding mistrust and criticisms raised from within towards their policies for history education. The main point of the controversies over the Battle of Okinawa is its treatment in the textbooks of Japanese history, in particular how to describe massive suicides committed by civilian residents in reference to the involvement of the Imperial Japanese Army (IJA) during the Battle.

The arguments of this chapter are threefold. Firstly, the domestic history textbook controversies over the Battle of Okinawa have deep roots of the history within which Okinawa has been absorbed in the Japanese state. Secondly, the controversies must be understood in line with the positioning of Okinawa within the notion of nationhood in the modern Japanese state. Lastly, a lack of policies for critical reviews of war-time events resulted in the tardy development of reconciliation about the Battle and the war in Japan.

\subsection{Collective Memory and Policy for Reconciliation}

Collective memory has trends. It is socially constructed, reflecting the dominant discourses of society (Halbwachs 1989). Therefore, in principle, collective memory is differentiated from 'objective' history. In reality, the history construed by the elites in society largely shares the elements of collective remembering, and often becomes compatible with it (Wertsch 2002: 20). Official interpretations of historical events are inseparable from, or often the direct reflection of, collective memory. Thus, national history is transmitted over the next generations differently along with the metamorphosis of the society.

Unquestionably, collective memory is not the collection of individuals' memories. In the cases of historical incidents of injustices, the memories of individual victims are sometimes alienated from collective memory, affected by the 'public' interest of concerning society. This discrepancy often results in the exposure of victimhood to political whims or the trivialisation of it. Such cases can be found in East Asia where the settlement of WWII was left more ambiguous than in Europe. For example, the Nanjing Massacre had barely been taught in Chinese schools until the death of Mao Zedong and the subsequent rise of Deng Xiaoping, because the history of 'national humiliation' was regarded as improper in the midst of nationbuilding (Mitter 2003). Agonies of A-bomb victims in Hiroshima and Nagasaki had not been discussed eagerly in Japan while the country was striving for national reconstruction, and have become part of collective memory for post-war Japanese along with the growth of anti-nuclear movement around the world.

Official interpretations about the dark side of national history or past injustices are largely affected by public memory. Over the past few decades, depressing histories have drawn intensive political and academic attention. As mentioned earlier, it has been a remarkable phenomenon that a number of governments and the state leadership try to correct past injustices in the form of formal apologies by reviewing the traditionally and broadly accepted perceptions of those incidents. The apologies 
were offered to victims who had been treated inequitably and often inhumanely by state authority because of their political creeds, religious faiths or racial origins. Regardless of the time of the wrongdoings-some were done in the remote past and others quite recently_offering such apologies has become a common phenomenon around the world from the turn of the century. Apologies resulted in reconciliation with the victims in some cases, and in others did not. Different results notwithstanding, policy makers in educational arena followed suit. Corrections of depiction and interpretation about those past incidents are reflected on the ideas and practices of public education, notably in history education.

Examples of such 'amendment of history', especially on WWII, are many. Apology by the French President in 1995 for the deportation of Jewish residents to Nazi 'death camps' was a symbolic one. Another apology to Holocaust victims was followed suit by the Swiss government in 1997. The Japanese Prime Minister stated his 'deep remorse' and 'heartfelt apology' to the victims of Japan's aggression during the war and its colonial rule in 1995, although the Japanese case did not bring about lasting reconciliation with the victims, revealing 'the difficulty of translating the western rhetoric of apology into terms of consistent with non-Western culture' (Barkan and Karn 2006: 7). As seen above, a growing number of countries have been trying to amend their wrongdoings by offering official apologies to the victims. Barkan and Karn (2006) view such acts as a propensity in recent political discourse, in particular after the end of the Cold War, and argue that this new political vigour is driven by the long-term tactics of the individual governments for constructing more mutually prosperous political and economic relationships in the region and the world. It is true that effective processes of those reconciliations between the victims and the perpetrators largely rest upon the political leadership on both sides, and moral courage especially of the latter. Moreover, there has been a globally growing public awareness of crime against humanity, which enables the legitimacy of the claims of victims to serve as effective political and educational means (Barkan 2000; Bekerman and Zembylad 2012).

Given the new trend in the history of modern states, this chapter explores the case of the Battle of Okinawa, whose treatment in history textbooks by the Ministry of Education has not brought about even a domestic reconciliation of interpretations about the war incident. The next section will demonstrate the points in question about the history textbook controversies on the Okinawan case, before discussing its historical background.

\subsection{Policy for History Textbook in Confrontation with Memories About the Battle of Okinawa}

The textbook authorisation system was introduced as part of post-war drastic democratisation of Japanese education under the US Military Occupation in Japan (1945-1952). Prior to the reform, school textbooks had been written by the state for 
primary schools (1903-1945) and secondary schools (1943-1945). Under the immediate post-war system, the right for authorising textbooks was in the hand of the local education boards. However, in the course of so-called 'right turn' with the intensification of the Cold War in East Asia, the right has been in the hand of the Minister of Education from 1955 until now. In the present system, textbook examination is conducted by the Textbook Authorization Research Council (TARC, Kyokayo-tosho Kentei Chosa Shingikai), mainly consisting of university professors and schoolteachers along with the Ministry's examination officers who have teaching experience in higher education. ${ }^{2}$ In general, the TARC announces the results of their examination of textbooks about 2 years before their actual use in schools in April. Unless the publishers get a simple 'Approval' or a simple 'Disapproval', they revise their textbook(s) based on TARC's 'opinions'. After the textbooks are authorised, each local education board selects a textbook of each subject for schools under its jurisdiction. Since 1963, the Ministry of Education has adopted the system of free supply of textbooks for compulsory education, that is, primary and lower secondary education. As of 2016, the Ministry spent 41.1 billion yen ( $0.8 \%$ of its budget) for the free distribution of 100 million textbooks throughout the country (Fig. 10.1). ${ }^{3}$

Despite its various controversial aspects, the Battle of Okinawa had not been in major disputes in history textbook issues until the 1980s. As will be mentioned later, stories related to the Battle received rather popular attention in the theatre or the literature in the 1950s and the 1960s. In the Battle, over 200,000 people died: 122,228 Okinawans (94,000 civilians and 28,228 soldiers), 65,908 Japanese soldiers from other prefectures and 12,520 US soldiers). ${ }^{4}$ The Okinawa Islands became the only ground battle theatre that involved civilian residents. Consequently, the military operations by both parties took a heavy toll on civilians, about one fourth of the population of Okinawa Prefecture. Among the tragedies that have befallen the war-time Okinawans, the most catastrophic one was a large number of suicidesabout 1000 altogether ${ }^{5}$ - committed collectively by the civilians during the Battle.

\footnotetext{
${ }^{2}$ http://www.mext.go.jp/a_menu/shotou/kyoukasho/gaiyou/04060901/1235089.htm. Accessed 3 August 2017.

${ }^{3}$ http://www.mext.go.jp/en/about/pablication/_icsFiles/afieldfile/2017/02/15/1374478_001.pdf. Accessed 15 August 2017.

${ }^{4} \mathrm{http} / / /$ www.peace-museum.pref.okinawa.jp/heiwagakusyu/kyozai/qa/q2.html. Accessed 10 August 2017.

${ }^{5}$ The figure in various literatures ranges from 700 to over 1000. In the case of the history textbook controversies over the suicide incident, the number of suicides is generally not a prime concern of dispute. Because of its relative precision, the author adopts the recently disclosed figure of 1143 suicides in 30 cases (Ryukyu Shimpo 2014, pp. 38-39). cf. According to Fujioka (2008) and Watanabe (2008), the number of suicide victims rose in the post-war period, influenced by the government's policy for extending the coverage of Senshobyo-sha Senbotsu-sha Izoku-tou Engo-ho, Act on Relief of War Victims and Survivors brought in 1952, to civilians who cooperated with the military or were involved in military actions. Fujioka argues that an increasing number of survivors and their relatives in the suicides began to claim that the suicides offered their lives to serve the state in the form of group suicides for the purpose of receiving the relief. Regarding the
} 


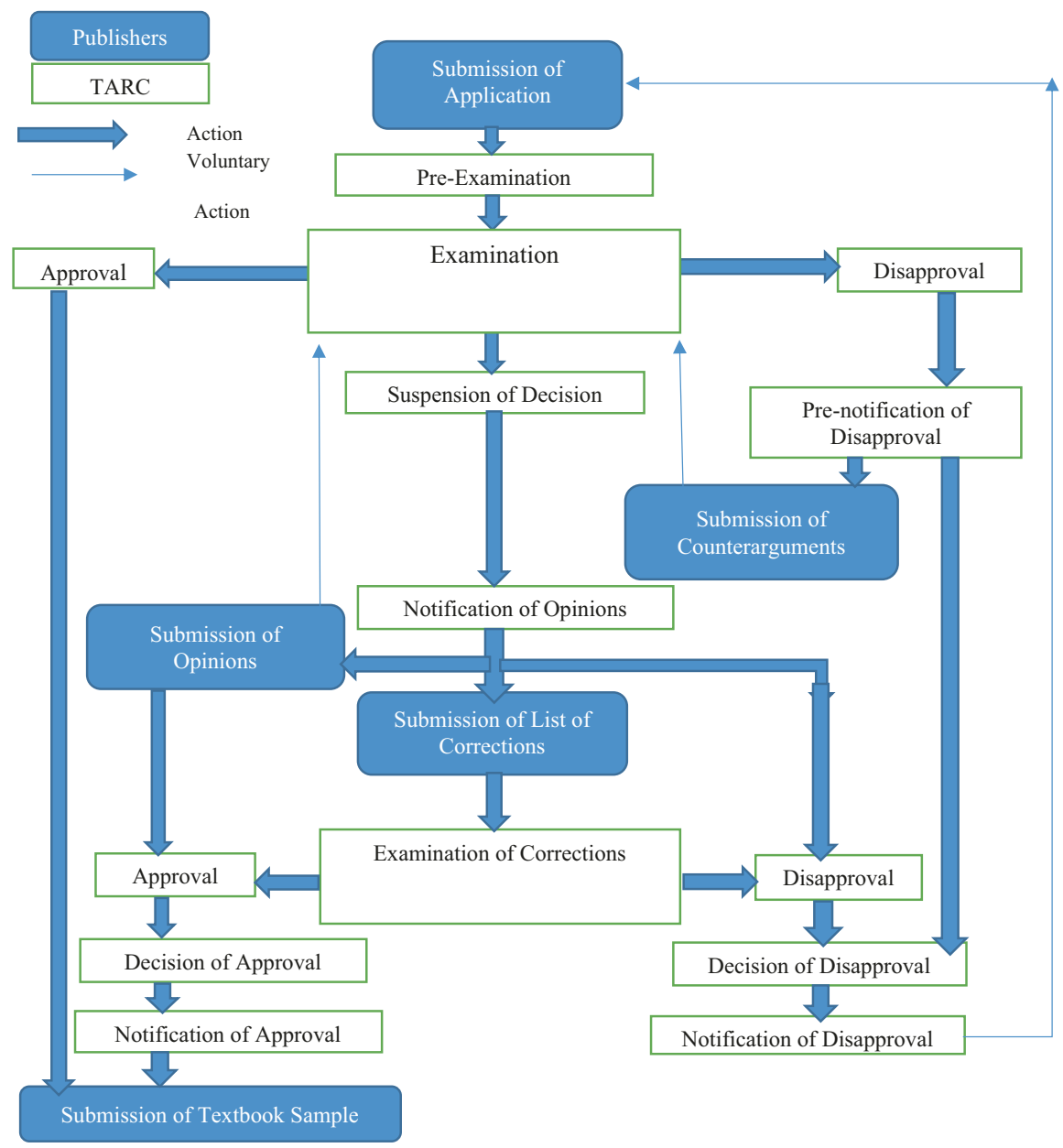

Fig. 10.1 Flow of textbook authorisation process (http://www.mext.go.jp/a_menu/shotou/kyoukasho/gaiyou/04060901/1235090.htm. Accessed 1 August 2017)

In many cases, the self-killings were carried out between family members, friends and neighbours. Why on earth were such tragic mass suicides committed by noncombatants in the war theatre?

A major dispute over the so-called 'group suicides'—shudan jiketsu—arose in the 1980s. It was started after the request made by the examination officers for

application of the Act in Okinawa, the Okinawa local government submitted its petition to the Ministry of Welfare for the coverage of non-combatants, such as student soldiers and student nurses (Ryukyu Shimpo 1953). Okinawa Times (1958) reported a possible rise in the number of 'war co-operators', including the group suicides, as the Ministry answered positively to the petition of the Alliance of the War Bereaved in Okinawa to extend the coverage of the Act to those who were 13 years old and younger during the Battle. 
adding the suicide incident to a textbook for upper secondary school. The preauthorisation version initially submitted to the TARC in 1983 stated in a footnote that:

Okinawa Prefecture became a battle field, and about 160,000 Okinawan men and women of all ages died cruelly. Among them, not a small number of people were killed by the Japanese military. (Ienaga 1993: 229)

According to the request, this description would not illustrate the whole picture of the Battle, because the largest number of civilian victims was caused by the 'group suicides', which should therefore be included in the footnote. The author of this textbook was Saburo Ienaga who had pursued legal fights against the Japanese government between 1965 and 1997 for his right of freedom of expression in textbook writing and for the claim of the unconstitutionality of the textbook authorisation system as such. ${ }^{6}$ In this case, Ienaga assumed that the intention of the Ministry's examination officers was to alleviate the horrible image of the massacre committed by the Japanese military by emphasising the 'group suicides', shudan jiketsu, as the term of 'jiketsu' would generally connote a voluntary and strong-minded act of selfkilling (Ienaga 1993: 232). ${ }^{7}$ Indeed, the 'group suicides' were broadly viewed —at least on the governmental side - as the virtuous acts of imperial subjects, who bravely avoided humiliation by the enemy as its prisoners of war (POWs) (Japan Defense Agency 1968: 252). While this textbook was in dispute in his third lawsuit that Ienaga partly won, he rewrote the text. The authorised version appeared as follows:

About 160,000 Okinawan men and women of all ages died cruelly by being killed in bombardment or driven into group suicides. Among them, not a small number of people were killed by the Japanese military. (Ienaga 1993: 232)

A larger controversy ensued in the late 2000s, which provoked massive protests by Okinawans. Based on TARC's 'opinions' given to Japanese history textbooks for upper secondary schools in April 2006, sentences and phrases which indicated the military's orders to civilians to commit the 'group suicides' were rewritten or rephrased. Consequently, all textbooks were approved in March 2007. Many Okinawans regarded this case as a distortion of history about the Battle. In September, about 110,000 local residents gathered a rally to protest the TARC's opinions for the revisions. After the civic movement, six publishers of eight textbooks submitted their applications to the Minister of Education for his permission to revise the rewritten texts again in November. The Minister asked the TARC's committee in charge of Japanese history to re-examine the textbooks.

\footnotetext{
${ }^{6} \mathrm{He}$ was also one of the authors of the first post-war history textbook that was issued in 1946 under the supervision of the General Headquarters of Supreme Commander for the Allied Powers (GHQ SCAP).

${ }^{7}$ In its exhibitions and publications, the Okinawa Prefectural Peace Memorial Museum-founded and run by the Okinawa Prefecture-uses the term 'forced group deaths', kyosei shudan shi, instead of the 'group suicides', shudan jiketsu.
} 
In its report, a TARC's committee in charge of Japanese history explained its initial decision by arguing that 'recent research and publications on the group suicides show that the existence of such orders is not necessarily evident' (TARC 2007: 6). The report also stated that 'it is not possible to confirm with all Okinawan residents who committed the suicides whether or not there were such military orders to the suicides. ... Thus, it would be proper to avoid definitive sentences about the existence of the military orders' (TARC 2007: 6). The Committee demonstrates their basic understanding as follows:

The group suicides occurred in the extraordinary situations within which civilian residents were dragged into the military battle at the end of the Pacific War. There were intricate backgrounds for this occurrence, such as education, instruction, and the inculcation of certain feelings during the period. In addition, there were various factors which created the situation the group suicides occurred. ... Therefore, oversimplified expressions in textbooks about the backgrounds and the factors which led to the group suicides might not enable students to understand the incident adequately. (TARC 2007: 8)

In short, although the TARC did not deny a certain involvement of the Japanese Imperial Amy in the group suicides, it did not accept that there were direct orders to the suicides by the Imperial Japanese Army to that effect.

Unlike the case of the 1980s, this case drew media and public attention outside Okinawa. After the re-examination of the once-rewritten textbooks, the Minister approved the publishers' request for restating the army's 'involvement' in the suicides in their textbooks on 26 December 2007, just in time for their actual use in April 2008. However, the restatement was possible on condition that the publishers should make sufficient reference to contextual information about the Battle and the suicides. In addition, the TARC maintained that the initial expressions about the 'suicides forced by the military' in definitive tones would still be 'misleading'. Okinawa Times (2007) issued a special edition on this case and underscored the voice of disappointment at the rejection of clear expressions about the military's compulsion, while major newspapers, like Asahi Shinbun (2007), showed more mixed views, including some appreciation of the reinstatement. The voice of Okinawans was powerful enough to have such political impact. On the day of his approval, the Minister, Kisaburo Tokai, announced his comment by mentioning 'our mission to take the thought of the people of Okinawa' and 'our intension to make efforts to further enhance learning about the Battle of Okinawa' in public education. ${ }^{8}$

The treatment of the Battle of Okinawa is complex, because a simple dichotomy between 'aggressors' and 'victims' does not fully work in this domestic case, considering the recent development of a variety of more complex perceptions about the history of WWII around the world. ${ }^{9}$ It is even more complex in the Okinawan case,

\footnotetext{
${ }^{8}$ http://kohoken.chobi.net/cgi-bin/folio.cgi?index=lb2\&query=/lib2/20071226.txt. Accessed 10 August 2017.

${ }^{9}$ Shift in historiography from narratives around the theme of nation-state to broader attention to 'everyday life' or 'ordinary people' modified the earlier simplistic dichotomy of victim versus perpetrator in understanding the war history. For example, narratives about war-time Germans as an aspect of victims are seen more than before in the literature and public culture.
} 
because it could be seen not as a completely 'domestic' matter in historical viewpoints. To tackle the intricacy of the case, the next section tries to trace how Okinawa and Okinawans were perceived within the notion of the Japanese nationhood by the central government and by themselves.

\subsection{A Slow and Complex Genesis of the Textbook Issue About the Battle of Okinawa}

\subsubsection{Assimilation and Differentiation of Okinawa in the Process of State Formation}

The modern history of Okinawa has been constantly exposed to policies for assimilation and differentiation both by the central and local governments. Military invasion of the Ryukyu Kingdom was started by a Japanese feudal fief in the early seventeenth century, and it was officially absorbed as Okinawa Prefecture into the Japanese state in 1879 during the Meiji Restoration. However, the political treatment of Okinawa by the central government was not equal to those of other prefectures in 'mainland' Japan, for example, delayed introduction of land reforms and conscription. All pre-WWII governors of Okinawa were despatched from the mainland, and few of the local authority officials, such as the Okinawan Bureau of Education, had been Okinawans. Because of its long distance from the metropolitan area and its different climate environment, Okinawa suffered from tardier industrial modernisation than other prefectures. Economic difficulties of Okinawans prompted their emigrations to Hawaii and South America. Between 1899 and 1937, about $10.5 \%$ of all Japanese emigrants $(641,677)$ were from Okinawa, the second largest emigration after Hiroshima Prefecture, and the retention ratio of Okinawan emigrants was the highest among all Japanese (Ishikawa 2005: 11-13). In sociocultural perspectives as well, Okinawans had been regarded as an inferior ethnic minority as opposed to the Yamato race, that is, the 'genuine Japanese' (Bhowmik 2012). There were social stigmas about Okinawans, which were associated with their Ryukyuan language and some lifestyles nurtured in a semi-tropical climate, unfamiliar to most Japanese people. The idea of 'Japanese progression' in terms of industriousness, hygiene and education was also highlighted by that of 'Okinawan backwardness', similar to those of Japanese colonies such as Taiwan (1895-1945) and Korea (1910-1945) (Christy 1997).

Nonetheless, Okinawa was not under the jurisdiction of the Bureau of Colonial Affairs unlike the colonies and was definitely positioned in naichi (inland) as opposed to gaichi (outer territories). In the context of pre-WWII Japan, the policy of Kominka - cultivating 'imperial subjects' for the state and the Emperor-was imposed upon all children and schools within the Empire. For example, the recitation of the Imperial Rescript on Education and rituals like bowing towards the Imperial Palace in Tokyo were forced to all children, regardless of the location of 
schools. However, the cultural assimilation policy of the Imperial Japanese Government functioned in Okinawa with more complexity than in the colonies. Along with efforts to maintain the sense of Okinawan cultural identity among the local people, the Okinawan local government deliberately maintained its policy for making Okinawa and Okinawans genuinely 'Japanese' and tried to be recognised as such by the central government.

The policy was reflected in education and other aspects of people's life. Initially in Okinawa, 14 primary schools were built in 1880, but the attendance of children in the schools was very limited. This was mainly due to economic difficulties and the rejection of 'Japanese culture' by the people (Miyagi 1997). Because the Ryukyu Kingdom had long maintained a tributary relationship with the Chinese dynasties, Okinawans felt more familiar with Chinese culture rather than Japanese one. However, coinciding with Japan's victory over China in 1895, their attitude to the mainland had changed. After the introduction of conscription in Okinawa, 25 years later than in other prefectures, Okinawan males gave up their traditional style of long hair. Women also began to stop their custom of drawing tattoos on the back of their hands. The conventional Okinawan names were gradually displaced by names that sound phonetically more 'Japanese'. With the rise of Japan as a modern state in international politics and economy, Okinawans began to abandon the culture and lifestyle of their native style and to be inclined to those of 'real Japanese' one (Miyagi 1997).

The most illuminating example was seen in the educational policy for language. In 1880, the institution called Kaiwa Denshusho was founded to train teachers who could function in the standard Japanese language. As in the major local authorities in Okinawa, the head of the institution came from the mainland. For the overall standardisation of the Japanese language, the Ministry of Education installed the subject of 'communication' in the nationwide school curriculum, but eventually abolished the subject except in Okinawa. There, a special textbook, Okinawa Taiwa, was issued for the subject. The Ministry of Education also had a special policy for Hokkaido, where there was an ethnic minority called Ainu. But the policy for emphasising standard Japanese in Okinawa was apparent in a comparative analysis of the special versions of Japanese language textbooks issued for the two prefectures respectively around the 1990s (Kai 2004: 50-55). Thanks to the ministerial policies and the absorption of them by the public, the attendance ratio of primary schools in Okinawa reached over $90 \%$ in the 1910s. The effort for cultural assimilation was made by the Okinawan educational authorities. Pupils were not permitted to use the Ryukyuan dialect after the third week of their entry into the primary school. They were watched with particular care by teachers in extra-curricular activities, for example, excursions, as children would tend to be less tense than in classroom studies (Kajimura 2006). A punishment for the use of the dialect, 'Dialect Placard', was introduced (Fig. 10.2).

Once a pupil spoke the dialect, he or she had to keep the placard hanging from the neck until the pupil found another violator. Within the system of mutual surveillance, the use of the local dialect among children was strictly forbidden in public schooling. 
Fig. 10.2 Dialect placard, Hogen-fuda (@Okinawa Prefectural Peace Memorial Museum)

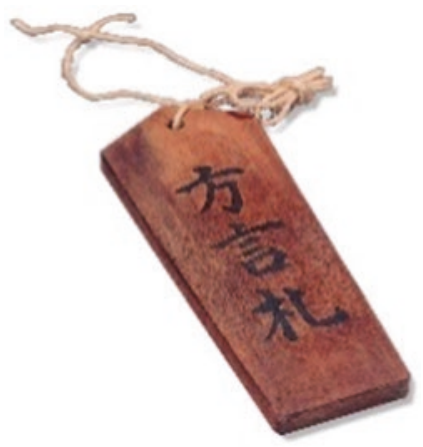

\subsubsection{Okinawan People in WWII}

As seen in the modern history of Okinawa, policies of assimilation and differentiation had clearly affected the life of Okinawan people. The treatment of Okinawa and Okinawans by the central government and, to a greater extent, by the Imperial Japanese Army had far distressing effects upon their life and history. The Okinawa Islands became the battle ground by the USA landing in Japan's homeland, along with the Ogasawara Islands, including Iwo Jima. However, as noted by the Governor of Okinawa, Okinawans feel that they were the only Japanese who had been forced to experience hardships on the ground battle, as the about 6000 residents of Ogasawara had been evacuated months before the battles began (Ryukyu Shimpo 2014: xvi). ${ }^{10}$

Special policy for Okinawa could be seen in the mobilisation of students too. Without an approval in the National Diet, the Ministry of the Army lowered the state-regulated draft age of 17 to 14 for students in Okinawa, Ogasawara and other island territories which were strategically detached from mainland Japan. In Okinawa, male students between 14 and 16 years old were drafted into Tekketsu Kinno-tai, Iron and Blood Corps for the Emperor. For females, nine units of student nurse were formed. Among them, the Himeyuri Student Nurse Corps took the heaviest death tolls. A survivor of Himeyuri recalled their experience that (Fig. 10.3):

We grew up during wartime and received an education whose goal was to nurture people willing to die for the country and for the Emperor. And we believed that Japan was fighting a holy war that was to bring happiness to all Asian people, ... But there is no such thing as a noble war. What we experienced in Okinawa was madness, and it was miserable beyond description. (Japan Times 2007)

\footnotetext{
${ }^{10}$ The Japanese government had attempted to evacuate Okinawans to the southern prefectures in Japan's mainland, but both the size of the population and the distance to the mainland hindered many successful evacuations, like the case of a passenger ship, Tsushima-maru, which was sunk by a US submarine in August 1944, on its way to Kagoshima Prefecture having 784 schoolchildren aboard.
} 
Fig. 10.3 Two boys of Tekketsu Kinno-tai taken prisoner by the US army on 17 June 1945 (C) Okinawa Prefectural Peace Memorial Museum). (The original photo data of Okinawa Prefectural Peace Memorial Museum will be attached in the final version)

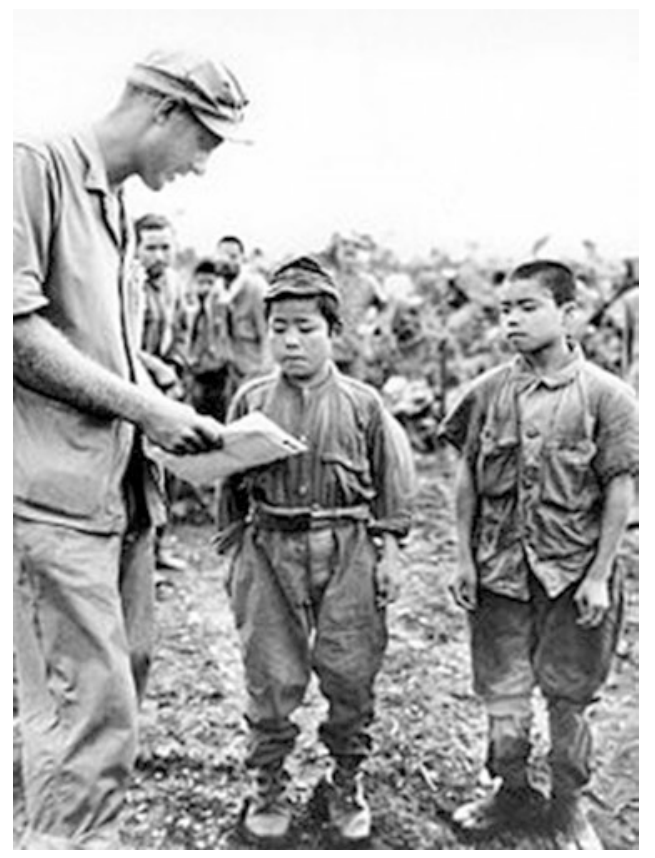

In history textbooks, those services of Okinawan boys and girls in the Battle were introduced but in a more heroic tone rather than a tragic one. In particular, the stories of the Himeyuri Corps were popularly read in novels and were watched on TV dramas and films in the 1950s and the 1960s.

As noted in history textbooks, Okinawan civilians were killed not only by US bombings from the air and the sea, but also by the soldiers of the Imperial Japanese Army. Some people were killed on suspicion of espionage, because they spoke their dialect which the soldiers did not understand. Others were forced to yield their shelters to the soldiers and were exposed to bombs. In the Yaeyama area, the Army compelled the civilians to be evacuated to malaria-infected mountainous zones, by ordering them to abandon their food and livestock in their residence. According to Yaeyama Peace Memorial Museum, 16,884 islanders in four villages were infected by malaria (53\% infection ratio), and 3647 died in total. ${ }^{11}$

The massive group suicides in question brought about over 1000 death tolls in 30 cases (Ryukyu Shimpo 2014: 38-39). They were committed between the middle of late March and early June 1945. The deaths were caused by hand grenades,

\footnotetext{
${ }^{11}$ The victims and their relatives of so-called 'Wartime Malaria' claimed official indemnity by the Japanese government for their suffering based on the Act on Relief of War Victims and Survivors. The government dismissed this claim and setup a special compensation fund for those sufferers instead. The Museum was established by this fund in 1999, as a branch institution of the Okinawa Prefectural Peace Memorial Museum. http://www.pref.okinawa.jp/yaeyama-peace-museum/toukannituite/leaflet_eng.pdf. Accessed 14 August 2017.
} 
improvised explosive devices, dynamites, poison injection, burning, drowning and stabbing. In Zamami village in the Kerama Island, $83 \%$ of the group suicides were committed by women, primary school pupils and younger children (Tobe 2016: 55). ${ }^{12}$ In other cases too, most victims were women and children. Japan's organised resistance in Okinawa ended on 22 June 1945, when Lt. Gen. Ushijima, Commanding General of the 32nd Army, killed himself to atone for the loss of the Battle. By its end, about $30 \%$ of schoolteachers and most students of normal schools lost their lives (Iijima 1972: 3-4).

\subsubsection{Okinawa as a 'Foreign Land' in Post-War Japan (1945-1972)}

At the onset of US landing in the Okinawa Main Island in April 1945, the establishment of the US Navy Military Government in Okinawa was proclaimed by C. W. Nimitz, US Navy Commander-in-Chief. By the proclamation, he as the 'Military Governor of the Islands of Nansei Shoto and Adjacent Waters' declared that all powers were in him in this area, and suspended the jurisdiction of the Japanese government over this area, including the Okinawa Islands (GRI 1957: 1). The GHQ detached Okinawa Prefecture from Japanese territories in February 1946 and established the US Civil Administration for the Ryukyu Islands (USCAR). Prior to the ratification of San Francisco Treaty in April 1952 whose Article 3 defined the US rule of Okinawa, USCAR formed the Government of the Ryukyu Islands (GRI), the Okinawan's civic authority under the control of the US military government. Okinawa Prefecture had been under the rule of a US trusteeship until its reversion to Japan on 14 May 1972.

Education was resumed informally in the POW camps by US support and control in the situations of extreme shortage of manpower and facilities. By pitching tents, 'schools' were founded, and one of the first schools was started as early as 7 May 1945, with 790 pupils under the 4th grade (395 males and 395 females) and 20 teachers (9 males and 11 females) (Okinawa Education Board 1977: 5-8). The US authorities provided the school with blackboards, music instrument, and other learning and playing equipment. Before textbooks were 'imported' from Japan in 1948, the Department of Education of GRI made textbooks of mimeographed copies. Measures for educational democratisation by the US authorities were taken as in the mainland, such as the suspension of Japanese history, geography and Shushin (moral education) and the prohibition of all ultra-nationalistic and militaristic activities. The so-called 6-3-3 school system was introduced in Okinawa in 1948, 1 year later than in mainland Japan. In the case of the mainland, the system functioned relatively well by legal endorsement of the newly established Fundamental Law of

\footnotetext{
${ }^{12}$ Tobe (2016) argues that this resulted from the 'line of command' which was strictly maintained by the headmen of individual communities in the traditionally patriarchal society of Okinawa.
} 
Education in 1947, but it did not in Okinawa as the enactment of the Law had to wait for 11 years after that (GRI-Education 1972: 54; Kaminuma 1962).

What was particularly unique about US education reforms in Okinawa was emphasis on local culture, including the language, arts and history (Hagiwara 2015). As demonstrated in Shurei no Hikari, a monthly magazine published by the US Military Government for Okinawans during the occupation, the US authority clearly intended to value the ideas of American democracy, Christianity and the unique culture of 'Ryukyu' and to separate Okinawa from Japan politically and culturally. The Basic Principles in Education were announced in 1953, and an Education Law was enacted in 1957. The US government noted the following principles:

1. The Education Department of Okinawa must not be under the auspices of the Japanese Ministry of Education, because it is against the principle of the establishment of the Ryukyu government.

2. Until the proper education law is enacted, the US government legislates the Ryukyu education laws.

3. The head of the Education Department of Okinawa can define criteria for teacher licences with the cooperation of the Ryukyu University.

4. The US government will support Okinawa to build and reform school buildings as long as the GARIOA ${ }^{13}$ fund continues (GRI-Education 1972: 55-56).

In US-ruled Okinawa, educational democratisation progressed in American ways. Political activities of schoolteachers or gathering were banned by the vetos exercised by the US Military Government against the bills passed by the Legislature of GRI. The directors of the Ryukyu University were unable to exercise their legal rights without the permission of the US authority (Hayashi 1963). The imported textbooks from Japan had to go through another check by the USA. As in the case of a US ban on a TARC-authorised textbook-Japanese History: The New Versionwritten by Ienaga et al. in 1959, emphasis on US military presence in post-war Japan was not tolerated by the US authority for the use in Okinawan schools (Taminato 2014: 89). During the entire period of the US rule, Okinawa suffered from disadvantage in education not only in terms of financial conditions or infrastructures but also students' opportunities for proceeding to upper educational institutions and their overall career development.

\subsection{Concluding Remarks}

Narratives about the victimhood in the Battle of Okinawa in history textbooks have shown distinct political sensitivity in the disputes of textbook controversies over Japan's war-time wrongdoings. In the case of Okinawa, the war-time Japanese were

\footnotetext{
${ }^{13}$ Government Appropriation for Relief in Occupied Area, emergency relief programmes provided for US-occupied areas, such as Austria, Germany and Japan.
} 
remembered as both aggressors and victims. However, the political sensitivity is not only based on the fact that Japanese civilians were killed by the army of their own country. The strategic significance notwithstanding, military and educational policies imposed upon war-time Okinawa reflected how it was positioned in the Japanese Empire and post-war Japan. Okinawans have been exposed to policies of assimilation and differentiation since its absorption into the Japanese state in the late nineteenth century. The policies were imposed upon the people along with the rhetoric of the purity of the 'homogenous Yamato (Japanese) race', which was an ideological driving force of Japanese colonialism. Since the onset of Okinawa Prefecture until the end of WWII, or arguably until today, Okinawa has been treated politically, socially and educationally as the 'others' - if not the 'stranger' — and recognised as such within Japanese society.

The gap between the public memory of the Okinawans about the Battle and the official views of it by the Japanese government and the Ministry of Education is considerable. On the other hand, the overturn of TARC's initial decision was unusual in itself, but what was extraordinary in the history of post-war textbook authorisation was the fact that the public voices of war victims made the Ministry reconsider its longstanding conventional views about the history of WWII. In this sense, the case of Okinawa illuminated the extraordinary processes and outcome of history textbook disputes which the Japanese government and the Ministry of Education have been coping with.

Certainly, reconciliation between the victims of the Battle of Okinawa and the state of Japan seems to be far from achievement. It is true that the timing and intensity of policies for reconciliation about past injustices are essentially influenced by contextual changes in international and domestic politics, as shown in Section 1. From the 1980s, the Japanese government and the Ministry of Education too have attempted to set their policies for reconciliation on their political agenda, yet not in its centre. There has been a lack of critical reviews about the wrongdoings committed in the name of the raison d'État of Japan as a modern state. In the case of Okinawa, however, a new trend opened by the Okinawan local government is notable. Okinawa Prefecture built the monument of Hiewa no Ishiji (Cornerstone of Peace) in 1995 in the Peace Memorial Park on Mabuni Hill, the southern lands' end of the Okinawa Main Island. It was the place where the Imperial Japanese Army founded its final headquarters in their last and the fiercest organised fight. In the monument, the names of all fallen individuals in the Battle are inscribed, regardless of their nationality or their positions in the Battle. ${ }^{14}$ The Okinawan local government has certainly lit a light of hope for a step forward to history education in Japan.

\footnotetext{
${ }^{14}$ According to Okinawa Prefecture, the monument bears the names of 241,414 people: 149,425 Okinawans; 77,417 Japanese from other prefectures; 14,009 Americans; 82 British; 34 Taiwanese; 82 North Koreans; and 365 South Koreans. http://www.pref.okinawa.jp/site/kodomo/heiwadanjo/ heiwa/7623.html. Accessed 15 August 2017. Translations of Japanese texts are by the author of this chapter, if noted otherwise.
} 


\section{References}

Barkan, E. (2000). The guilt of nations: Restitution and negotiating historical injustices. New York: W. W. Norton \& Company.

Barkan, E., \& Karn, A. (2006). Group apology as an ethical imperative. In E. Barkan \& A. Karn (Eds.), Taking wrongs seriously: Apologies and reconciliation (pp. 3-30). Stanford: Stanford University Press.

Bekerman, Z., \& Zembylad, M. (2012). Teaching contested narratives: Identity, memory and reconciliation in peace education and beyond. Cambridge: Cambridge University Press.

Bhowmik, D. (2012). Subaltern identity in Okinawa. In M. M. Marson \& H. J. S. Lee (Eds.), Reading colonial Japan: Text, context, and critique (pp. 90-108). Stanford: Stanford University Press.

Christy, A. S. (1997). Making of Imperial subjects in Okinawa. In T. E. Barlow (Ed.), Formations of Colonial Modernity in East Asia (pp. 141-169). Durham: Duke University Press.

Fujioka, N. (2008). Okinawa Shudan-Jiketsu no Shinso to Kyokasho Kentei [The truth of the group suicides in Okinawa and textbook examination]. Kokutai Bunka, 1009, 8-29.

GRI-Legislature (Administrative Section, Secretariat of the Legislature, Government of the Ryukyu Islands). (1957). USCAR legislation, 1957: A complete collection of outstanding proclamations, ordinances and directives with amendments thereto issued by the United States civil Administration of the Ryukyu Islands and its predecessors since 1945. Naha: Kyodo Printing Company.

GRI-Education (The Department of Education, Government of the Ryukyu Islands). (1972). Okinawa ni okeru Sengo no Kyoiku no Ayumi [History of education in post-war Okinawa]. Monbu Jiho, 1139, 53-57.

Hagiwara, M. (2015). Senryo Shoki ni okeru Rekishi-kyoiku no Sikou-sei [The intension of history education in the early occupation period]. Nihon no Kyoikushigaku, 58, 58-70.

Halbwachs, M. (1989). Shugo-teki kioku [On collective memory]. Tokyo: Kohrosha.

Hayashi, M. (1963). Okinawa ni okeru Kyoiku no Tatakai [Fight for Education in Okinawa]. Bunka Hyoron, 21, 22-34.

Ienaga, S. (1993). Misshitsu. In Kentei no Kiroku [Record of Textbook Examination 'behind Closed Doors']. Tokyo: Meicho Kankokai.

Iijima, S. (1972). Okinawa ni okeru Kyoiku no Kadai to Tenbo [Problems and visions of education in Okinawa]. Monbu Jiho, 1139, 2-9.

Ishikawa, T. (2005). Okinawa-ken ni okeru Shutsu-Imin no Rekishi oyobi Shutu-Imin Yoin-Ron [History emigration from Okinawa prefecture and accounts on emigration motives]. Imin Kenkyu, 1, 11-30.

Japan Defense Agency, The National Institute for Defense Studies, Military History Department. (1968). Okinawa Homen Rikugun Sakusen [Army Operations in Okinawa]. Tokyo: Asagumo Shinbunsha.

Japan Times. (2007). "Student nurse recalls horror of Okinawa fighting", 28 December:3.

Kai, Y. (2004). Kokugo Kyokasho ni okeru Kogo-buntai Sentaku no Keiki [Movement for the selection of colloquial language style in Japanese language textbooks]. Nihongo to Nihonbungaku, 39, 49-66.

Kajimura, M. (2006). Okinawa no Hyojun-go Kyoiku-shi Kenkyu-Meiji-ki no Tsuzurikarakyoiku wo Chushin-ni [Research on history of education for the standard Language in Okinawa-Composition education in the Meiji period]. Ryukyu Daigaku Kyoikugakubu Kiyo, $68,1-10$.

Kaminuma, H. (1962). Okinawa Kyoiku Sho-shi [Short history of education in Okinawa]. Tokyo: Nanpo Doho Engokai.

Mitter, R. (2003). Old ghosts, new memories: China's changing war history in the era of post-Mao politics. Journal of Contemporary History, 38(1), 117-131.

Miyagi, H. (1997). Kominka Kyoiku no Higeki [The tragedy of Kominka Education]. Shakai Kyoiku, 41(6), 50-55. 
Okinawa Education Board (Okinawa-ken Kyoiku Iinkai). (Ed.). (1977). Okinawa no Sengo Kyoikushi [History of Education in Post-war Okinawa]. Naha: Okinawa Prefecture Education Board.

Okinawa Times. (1958). Sarani Fueru "Sentou Kyoryokusha", Shudan Jiketu ya go no Teikyo, 13-sai Ikamo Tekiyou no Mikomi [Further rise of the number of 'military co-operators', group suicides and offering shelters, Most likely including 13 years old and over]. 9 August (Afternoon Edition): 3.

Okinawa Times. (2007). Gun ga Kyosei' Mitomezu ['The military forced (the suicides)' Disapproved]. 26 December (Special Edition): 1.

Ryukyu Shimpo. (1953). Senbotsu-gakuto mo Gunjin Atsukai ni [Treating fallen students soldiers as soldiers]. 29 August: 3.

Ryukyu Shimpo (Ed.). (2014). Descent into hell: Civilian memories of the Battle of Okinawa. Portland: Merwin Asia.

Shinbun, A. (2007). Kyokasho Kentei: Okinawa Hyouka to Fuman [Textbook examination: Positive valuation and discontent in Okinawa], 27 December: 35.

Taminato, C. (2014). Okinawa and textbook lawsuits. In The Committee for the 100th-Anniversary of the Birth of Saburo Ienaga (Ed.), The 100th Anniversary of the Birth of Saburo Ienaga: Constitution, History, Textbook Lawsuits (pp. 89-91). Tokyo: Nihon Hyoronsha.

TARC (TARC, Committee of Japanese History). (2007). Heisei 18-nendo Kentei Kettei Kotogakko Nihon-shi Kyokasho no Teisei-shinsei ni kansuru Iken ni Kakawaru Chosa-shingi ni Tsuite [Report on the research deliberation about applications for revisions in Japanese history textbooks for upper secondary schools decided in the academic year of 2006]. Tokyo.

Tobe, H. (2016). Okinawa-sen no Kioku to Gendai [Memory of the Battle of Okinawa and the present time]. Rekishi Chiri Kyoiku, 850, 52-59.

Watanabe, N. (2008). Rekishi Kyoiku wo Yugameru mono [What distorts history]. WiLL, 8, 34-43. Wertsch, J. V. (2002). Voices of collective remembering. Cambridge: Cambridge University Press.

\begin{abstract}
Masako Shibata is an associate professor in the Doctoral Program of International and Advanced Japanese Studies of the Graduate School of Humanities and Social Sciences at the University of Tsukuba, Japan. Her work on comparative education and history of education has developed from her MA (1996-1997) and PhD (1998-2001) at UCL, the Institute of Education, University of London. Since she started her full-time work at Tsukuba in 2005, she has been working steadily on the theme of history education about World War II in the countries that had been heavily involved in the war. While the major focus is on Japan and Germany, the scope of her research has recently been expanded to their neighbouring countries in Asia and Europe. She is also a member of the International Advisory Committee for the journal of Research in Comparative and International Education. E-mail: mshibata@sakura.cc.tsukuba.ac.jp.
\end{abstract}

Open Access This chapter is licensed under the terms of the Creative Commons Attribution 4.0 International License (http://creativecommons.org/licenses/by/4.0/), which permits use, sharing, adaptation, distribution and reproduction in any medium or format, as long as you give appropriate credit to the original author(s) and the source, provide a link to the Creative Commons licence and indicate if changes were made.

The images or other third party material in this chapter are included in the chapter's Creative Commons licence, unless indicated otherwise in a credit line to the material. If material is not included in the chapter's Creative Commons licence and your intended use is not permitted by statutory regulation or exceeds the permitted use, you will need to obtain permission directly from the copyright holder.

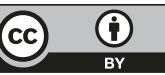

